\title{
Detection of Babesia odocoilei in Ixodes scapularis Ticks Collected in Southern Ontario, Canada
}

\author{
John D. Scott ${ }^{1, *}$, Emily L. Pascoe ${ }^{1}$, Muhammad S. Sajid ${ }^{1,2}$ and Janet E. Foley ${ }^{1}$ \\ 1 Department of Medicine and Epidemiology, School of Veterinary Medicine, University of California Davis, \\ Davis, CA 95616, USA; elpascoe@gmail.com (E.L.P.); jefoley@ucdavis.edu (J.E.F.) \\ 2 Faculty of Veterinary Science, University of Agriculture, Faisalabad 38040, Pakistan; drsohailuaf@uaf.edu.pk \\ * Correspondence: jkscott@bserv.com
}

check for updates

Citation: Scott, J.D.; Pascoe, E.L.; Sajid, M.S.; Foley, J.E. Detection of Babesia odocoilei in Ixodes scapularis Ticks Collected in Southern Ontario, Canada. Pathogens 2021, 10, 327. https://doi.org/10.3390/pathogens 10030327

Academic Editor: Ellen Knuepfer

Received: 5 February 2021

Accepted: 4 March 2021

Published: 10 March 2021

Publisher's Note: MDPI stays neutral with regard to jurisdictional claims in published maps and institutional affiliations.

Copyright: (C) 2021 by the authors. Licensee MDPI, Basel, Switzerland. This article is an open access article distributed under the terms and conditions of the Creative Commons Attribution (CC BY) license (https:/ / creativecommons.org/licenses/by/ $4.0 /)$.

\begin{abstract}
Tick-borne zoonotic diseases have an economic and societal impact on the well-being of people worldwide. In the present study, a high frequency of Babesia odocoilei, a red blood cell parasite, was observed in the Huronia area of Ontario, Canada. Notably, 71\% (15/21) blacklegged ticks, Ixodes scapularis, collected from canine and feline hosts were infected with B. odocoilei. Consistent with U.S. studies, $12.5 \%(4 / 32)$ of questing I. scapularis adults collected by flagging in various parts of southwestern Ontario were positive for B. odocoilei. Our data show that all B. odocoilei strains in the present study have consistent genetic identity, and match type strains in the GenBank database. The high incidence of B. odocoilei in the Huronia area indicates that this babesial infection is established, and is cycling enzootically in the natural environment. Our data confirm that B. odocoilei has wide distribution in southern Ontario.
\end{abstract}

Keywords: Babesia odocoilei; piroplasm; babesiosis; ticks; Ixodes scapularis; parasitism; domestic cats; domestic dogs; Canada

\section{Introduction}

Tick-borne zoonotic pathogens cause many diseases that have considerable medical, veterinary, and economic impact worldwide. In North America, Babesia odocoilei is a single-celled microorganism that belongs to the genus Babesia (Apicomplexa: Piroplasmida: Babesiiidae). This intraerythrocytic piroplasm infects terrestrial vertebrate hosts [1]. Clinical manifestations of babesiosis range from a silent infection to a fulminating malaria-like disease to severe hemolysis that can infrequently result in human death [2-12]. Babesia infection is normally transmitted to humans by a tick bite; however, this babesial hemoparasite can be passed from infected individuals to others via blood transfusion [13-15], organ transplantation [16], and maternal-fetal transmission [17,18]. Babesia that are pathogenic to humans include B. crassa, B. duncani, B. divergens, B. microti, B. venatorum, Babesia divergens-like MO-1, Babesia sp. KO1, Babesia sp. XXB/HangZhou, Babesia sp. TW1, and Babesia spp. CA1, CA3, and CA4 [7,19-22]. Around the globe, there are at least 111 valid Babesia species [1].

Members of certain biological families, such as cervids and bovids, are reservoir hosts of B. odocoilei. Both feral and captive white-tailed deer, Odocoileus virginianus (Mammalia: Cervidae), are reservoir-competent hosts of B. odocoilei [23-25]. As well, wapiti/elk (Cervus elaphus canadensis), reindeer (Rangifer tarandus tarandus), and caribou (Rangifer tarandus caribou) are native reservoirs of B. odocoilei [26].

Although it was initially believed that B. odocoilei was non-pathogenic [27-30], it is now recognized as a cause of cervid babesiosis, a disease that can be fatal for cervids, such as white-tailed deer, caribou and wapiti, particularly immunocompromised or excessively stressed individuals [25,26,31]. More recently, B. odocoilei has been detected in bovids, such as desert bighorn sheep (Ovis canadensis nelsoni), musk oxen (Ovibos moschatus), yak 
(Bos grunniens), and markhor goat (Capra falconeri), including areas outside of the range of I. scapularis [32,33].

The blacklegged tick, Ixodes scapularis (Acari: Ixodidae), is the principal vector of B. odocoilei. This ixodid tick species parasitizes at least 150 terrestrial vertebrates (avian, mammalian, reptilian), including humans, songbirds, and white-tailed deer [34,35]. Once a host-seeking I. scapularis tick becomes infected with B. odocoilei [25,36-39], this babesial infection can be sustained by transstadial passage (larva to nymph or nymph to adult) and by transovarial transmission (female to eggs to larvae). Blacklegged ticks can perpetuate B. odocoilei throughout all life stages [25,37-39]. East of the Rocky Mountains, I. scapularis closely coincides with the distribution of white-tailed deer $[25,27]$. The wide dispersal of B. odocoilei-infected ticks is facilitated by migratory songbirds, especially during northward spring migration $[35,40,41]$.

The primary aim was to determine the distribution of $B$. odocoilei in questing and animal-derived I. scapularis ticks in southern Ontario.

\section{Materials and Methods}

\subsection{Tick Collection}

Questing ticks were collected by flagging low-lying vegetation in the southern part of southwestern Ontario within the Carolinian forest region from 24 to 26 April 2019. At a more northerly location in the Huronia area, veterinarians and technicians collected attached, engorged ticks from domestic dogs and domestic cats from 2 to 27 May 2019. These attached ticks were removed using superfine-tipped stainless steel forceps, and ticks from each host were stored in a tightly sealed microtube containing $94 \%$ ethanol. Each microtube was labelled with a tick identification number. A white, vinyl-backed flannel cloth attached to a telescoping, aluminum pole was employed to collect questing ticks. Blood-fed and questing ticks were identified to species by using microscopy and taxonomic keys [34,42].

\subsection{DNA Extraction, $P C R$, and Sequencing}

To extract DNA from unfed ticks, an ammonium hydroxide protocol (unfed ticks) [35], or the Qiagen DNeasy Blood and Tissue Kit (Qiagen, Valencia, CA, USA) following the manufacturer's protocol for animal tissue was used. The resulting DNA was stored at $-20{ }^{\circ} \mathrm{C}$ until PCR was performed. Amplification of the $18 \mathrm{~S}$ rRNA gene of Babesia was performed as previously described using the BJ1 (5'-GTC-TTG-TAA-TTG-GAA-TGA-TGG$\left.3^{\prime}\right)$ and BN2 (5'-TAG-TTT-ATG-GTT-AGG-ACT-ACG-3') primers [43]. Amplicons were visualized by UV transillumination on a $1 \%$ agarose gel containing GelStar nucleic acid stain (Lonza, Rockland, ME, USA), and those that were 400-500 nucleotides in length, were excised from the gel, and prepared for DNA sequencing to confirm Babesia presence and species using the QIA amp DNA Kit (Qiagen, Valencia, CA, USA). DNA sequencing was performed at the University of California Davis Sequencing facility using the Big Dye Terminator cycle sequencing kit (Applied Biosystems, Foster City, CA, USA) and PCR primers.

\subsection{Phylogenetic Analysis}

End-reading errors were removed from sequences and, when possible, ambiguous nucleotides were manually corrected. Sequences were compared to those published in GenBank using the BLAST database search program (https:/ / blast.ncbi.nlm.nih (3 November 2020). The phylogenetic tree was constructed based on select published sequences of Babesia species (B. odocoilei, B. bovis, B. conradae, B. divergens, B. duncani, B. canis canis, B. gibsoni, B. microti, and B. vulpes) downloaded from GenBank. Babesia bovis was used as the outgroup species. All sequences were trimmed to the same length (445 nucleotides, including those absent in some species), and were aligned using the MUSCLE algorithm [44]. Phylogeny was resolved using the maximum likelihood method in MEGA 10.0.5 [45]. This general time reversible model facilitated gamma distribution and invariant sites (number 
of discrete categories equals five) was determined by jModeltest 2.1.10 [46]. Consensus was achieved by bootstrapping based on 1000 pseudoreplicate datasets generated from the original sequence alignments.

\section{Results}

\subsection{Tick Collection}

Between 24 April and 22 May 2019, a grand total of 53 I. scapularis adults (males, $\mathrm{n}=13$; females, $\mathrm{n}=40$ ) were collected from 14 locations in southern Ontario). These collections were conducted within two different forested areas (Great Lakes-St. Lawrence and Carolinian). Flagging was done in the Carolinian forest region, whereas canine- and feline-derived ticks were obtained from three veterinary clinics located in the Huronia area (Figure 1). Collections of I. scapularis comprised of 32 ticks (males, $\mathrm{n}=13$; females, $\mathrm{n}=19$ ) collected by flagging, and 21 females collected from 21 companion animals (domestic dogs, $\mathrm{n}=17$; domestic cats, $\mathrm{n}=4$ ).

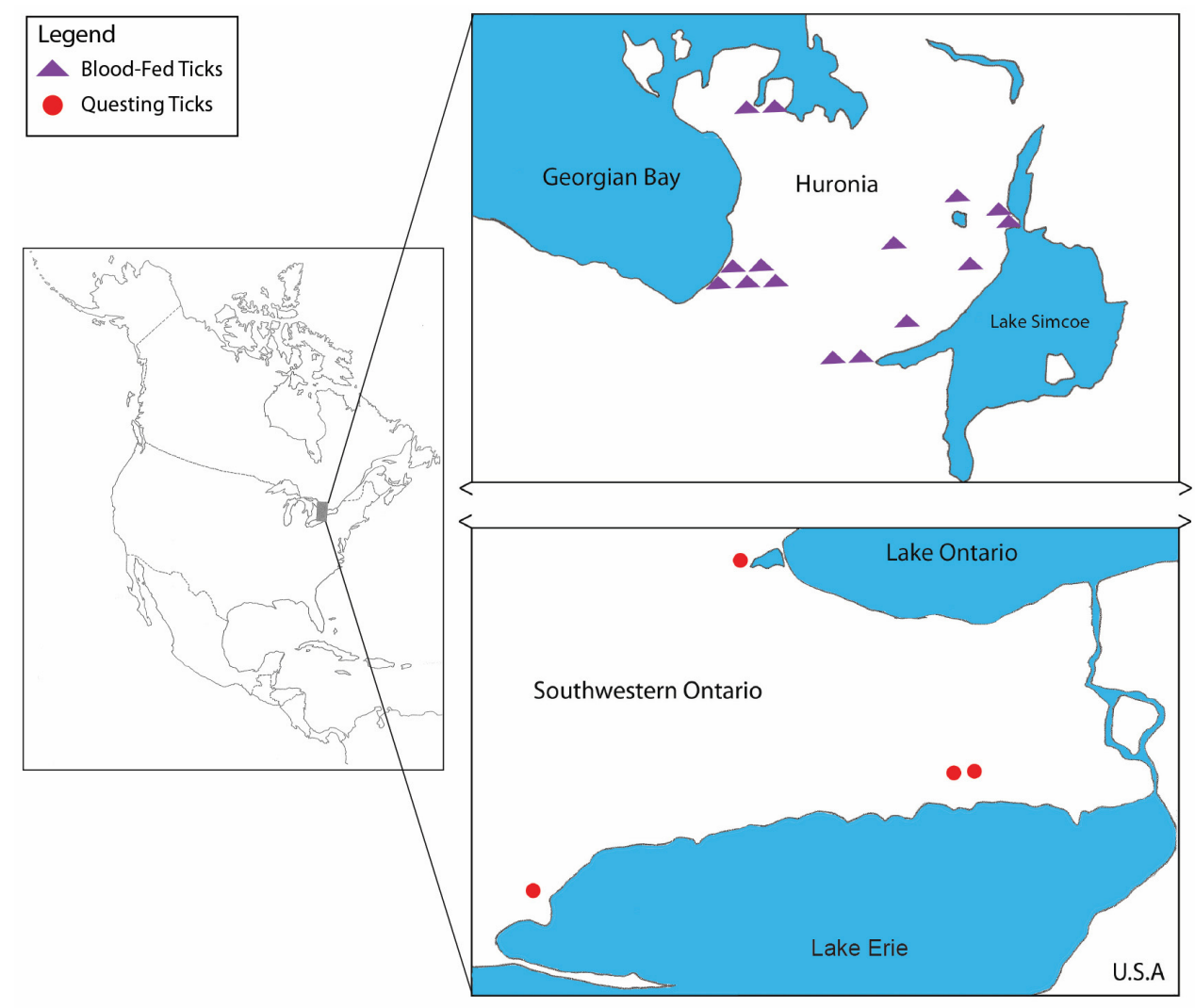

Figure 1. Map shows locations where Ixodes scapularis females were positive for Babesia odocoilei in southern Ontario, Canada. Purple triangles designate positive ticks collected from domestic dogs and domestic cats. Red dots represent positive ticks collected by flagging low-lying vegetation.

\subsection{Babesia Detection}

Of the 53 ticks, 35.8\% ( $n=19)$ tested positive for Babesia DNA (Tables 1 and 2). The majority of positive ticks were from dogs $(68.4 \%, n=13)$, plus two from cats $(10.5 \%)$, and four by flagging (21.1\%; Table 2). All positive samples were confirmed to be B. odocoilei based on $99.72-100 \%$ similarity to sequences published in GenBank (Table 1). With the exception of three male ticks collected at flagging sites (Dundas, Turkey Point, Wainfleet bog), all Babesia-positive ticks were adult females (Table 1). 
Table 1. Detection of Babesia odocoilei in Ixodes scapularis adults collected in southern Ontario, 2019.

\begin{tabular}{lccc}
\hline \multirow{1}{*}{\multicolumn{1}{c}{ Source }} & \multicolumn{2}{c}{ Number of B. odocoilei-Positive Ticks (\%) } \\
\cline { 2 - 4 } General sampling & Female(s) & Male(s) & Total Tick(s) \\
Cat & $2 / 4(50)$ & $0(0)$ & \\
Dog & $13 / 17(76.5)$ & $0(0)$ & $2 / 4(50)$ \\
Vegetation & $1 / 19(5.3)$ & $3 / 13(23.1)$ & $4 / 32(12.5)$ \\
Cat and dog sampling & & & \\
Barrie & $2 / 2(100)$ & $0(0)$ & $2 / 2(100)$ \\
East Wasaga & $0 / 1(0)$ & $0(0)$ & $0 / 1(0)$ \\
Orillia & $1 / 2(50)$ & $0(0)$ & $1 / 2(50)$ \\
Oro Medonte & $3 / 3(100)$ & $0(0)$ & $3 / 3(100)$ \\
Penetanguishene & $2 / 3(66.7)$ & $0(0)$ & $2 / 3(66.7)$ \\
Severn Township & $1 / 1(100)$ & $0(0)$ & $1 / 1(100)$ \\
Warmister & $1 / 1(100)$ & $0((0)$ & $1 / 1(100)$ \\
Wasaga Beach & $5 / 7(71.4)$ & $0(0)$ & $5 / 7(71.4)$ \\
Woods Beach & $0 / 1(0)$ & $0(0)$ & $0 / 1(0)$ \\
Flagging vegetation & & & \\
Dundas & $03(0)$ & $1 / 3(33.3)$ & $1 / 6(16.7)$ \\
Port Burwell & $0 / 6(0)$ & $0(0)$ & $0 / 6(0)$ \\
Thorold & $0 / 3(0)$ & $0 / 3(0)$ & $0 / 6(0)$ \\
Turkey Point & $0 / 4(0)$ & $1 / 4(25.0)$ & $1 / 8(12.5)$ \\
Wainfleet Bog & $1 / 3(33.3)$ & $1 / 3(33.3)$ & $2 / 6(33.3)$ \\
\hline
\end{tabular}

Table 2. Results of DNA sequence analysis and GenBank accession numbers of Babesia odocoilei detected in questing and blood-fed Ixodes scapuaris ticks in southern Ontario, 2019.

\begin{tabular}{|c|c|c|c|c|c|c|c|c|}
\hline & & & Date & Sequence & BLAS & Results & & GenBank \\
\hline Tick ID & Location & Source & Collected & Length & $\%$ of Type Strain & Score & E-Value & Accession No. \\
\hline CN19-2-2 & Dundas & flagging & $24 \mathrm{Apr}$ & 263 & 100 & 521 & $7 e-144$ & MW182495 \\
\hline CN19-5-2 & Wainfleet Bog & flagging & $24 \mathrm{Apr}$ & 100 & 100 & 198 & $4 e-47$ & MW182496 \\
\hline CN19-6-1 & Wainfleet Bog & flagging & $24 \mathrm{Apr}$ & 163 & 99.37 & 307 & $1 e-79$ & MW182497 \\
\hline CN19-8-2 & Turkey Point & flagging & $25 \mathrm{Apr}$ & 152 & 100 & 301 & $7 e-78$ & MW182498 \\
\hline CN19-79 & Penetanguishene & cat & 02 May & 265 & 100 & 525 & $5 e-145$ & MW182499 \\
\hline CN19-80 & Penetanguishene & $\operatorname{dog}$ & 14 May & 212 & 100 & 416 & $2 e-112$ & MW182500 \\
\hline CN19-86 & Wasaga Beach & dog & $30 \mathrm{Apr}$ & 357 & 100 & 706 & 0 & MW182501 \\
\hline CN19-87 & Wasaga Beach & dog & 03 May & 361 & 99.72 & 708 & 0 & MW182502 \\
\hline CN19-88 & Wasaga Beach & dog & 09 May & 358 & 99.72 & 200 & 0 & MW182503 \\
\hline CN19-89 & Wasaga Beach & dog & 10 May & 440 & 100 & 872 & 0 & MW182504 \\
\hline CN19-90 & Wasaga Beach & dog & 10 May & 434 & 100 & 860 & 0 & MW182505 \\
\hline CN19-91 & Severn Township & dog & 07 May & 440 & 100 & 872 & 0 & MW182506 \\
\hline CN19-92 & Oro Medonte & dog & 14 May & 387 & 100 & 767 & 0 & MW182507 \\
\hline CN19-93 & Barrie & dog & 15 May & 429 & 100 & 848 & 0 & MW182508 \\
\hline CN19-94 & Orillia & dog & 16 May & 429 & 100 & 850 & 0 & MW182509 \\
\hline CN19-95 & Warmister & dog & 17 May & 429 & 100 & 850 & 0 & MW182510 \\
\hline CN19-96 & Oro Medonte & dog & 19 May & 429 & 100 & 850 & 0 & MW182511 \\
\hline CN19-98 & Oro Medonte & dog & 23 May & 429 & 100 & 850 & 0 & MW182512 \\
\hline CN19-99 & Barrie & cat & 24 May & 429 & 100 & 850 & 0 & MW182513 \\
\hline
\end{tabular}

Between one and eight ticks (mean $=3.79$ ) were collected from each location, and Babesia-positive ticks were collected from ten of the 14 sampled locations. The number of positive I. scapularis ticks collected at each positive location in both forested area was low $(1-5)$, but prevalence ranged between $12.5-100 \%$ (mean $=65.06 \%$; Table 1 ). Only ten of the $19 \mathrm{~B}$. odocoilei sequences were of ample quality and length to perform phylogenetic analysis (CN19-89-CN19-99). These sequences were 100\% similar to one another and to three reference strains of B. odocoilei downloaded from GenBank (Table 2, Figure 2). 


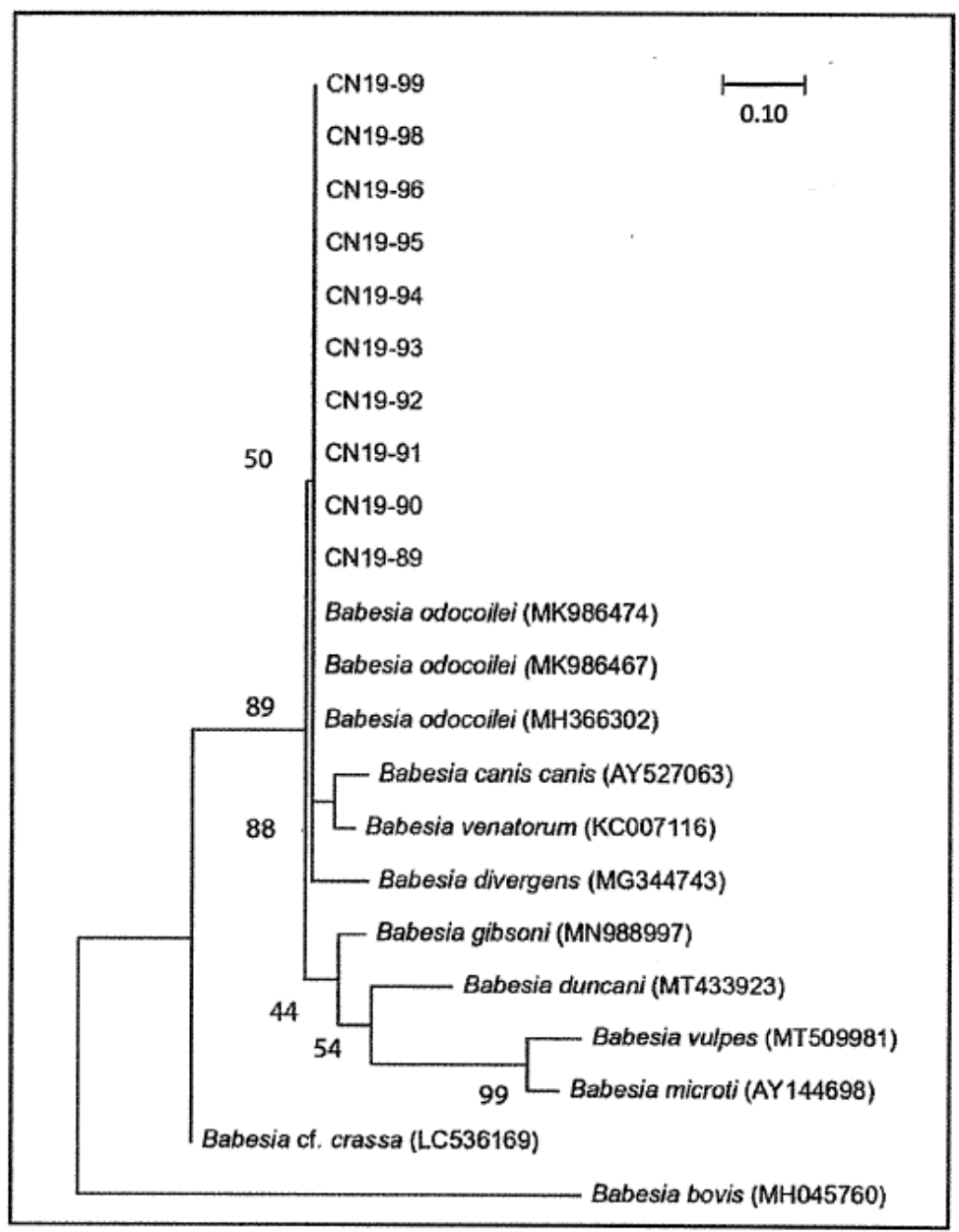

Figure 2. Maximum likelihood phylogenetic tree of $18 \mathrm{~S}$ rRNA sequences from Babesia positive Ixodes scapularis ticks collected in southern Ontario in 2019. All sequences were trimmed to 445 nucleotides in length (including those absent to some species) and aligned using the MUSCLE algorithm. Phylogeny was resolved using a gamma distribution with invariant sites, and consensus was achieved by bootstrapping based on 1000 pseudoreplicate datasets generated from the original sequence alignments. Alphanumeric values in brackets denote published sequences. Babesia bovis is the outgroup species. The scale bar signifies the percentage of genetic variation along tree branches. Sequences from ticks are available in GenBank (accession numbers: MW182504-MW182513).

\section{Discussion}

Here we report the presence of Babesia in I. scapularis ticks from ten of 14 sampled locations in Ontario, Canada, collected either by flagging low-lying vegetation or from domestic cats and dogs (Table 1). Babesia DNA was detected in 19 (35.8\%) of 53 collected ticks. Our results are in concordance with previous studies conducted in the U.S.A. where $11-15 \%$ of the questing blacklegged tick adults collected from established populations were positive for B. odocoilei [47,48]. Although the gender of I. scapularis adults may seem disproportionate (Table 1), the ratio of males to females are balanced in nature genetically reflecting a 50:50 ratio. Based on deer tracks along trails, we observed that an I. scapularis-O. virginianus interface was present in each of the woodland and ecotone locations flagged. The high incidence of B. odocoilei in I. scapularis ticks in the Huronia area suggests that an epizootic, babesial infection is present in the local white-tailed deer population [23-25]. To our knowledge, this is the first time that $B$. odocoilei has been detected in ticks collected from dogs and cats in Canada. Researchers in Indiana reported one B. odocoilei-positive I. scapularis in 15 adults collected from a domestic dog [49]. Globally, certain other Babesia spp. (B. canis sensu stricto, B. gibsoni, B. microti, B. vogeli) can infect either cats or dogs [50]. 
In addition, B. conradae is associated with canine-feeding ticks and host dogs [51,52]. Babesia DNA, determined to be $97.8 \%$ similar to $B$. odocoilei, has been detected in ticks collected from dogs in Japan [53], whilst B. vogeli and B. microti have been detected in ticks associated with pet cats [54-56].

Babesia odocoilei can either be maintained in I. scapularis ticks by transstadial passage and/or transovarial transmission. All B. odocoilei-positive ticks in the present study were adults, and it is likely that they became infected during a previous developmental life stage while feeding on an infected reservoir host. As we did not draw blood from domestic cats and domestic dogs, we do not know if these companion animals play a role as reservoir hosts of B. odocoilei. This aspect warrants further investigation.

During the past half century, several tick-pathogen studies in North America have demonstrated that $B$. odocoilei has a wide distribution. In the U.S.A., the pathogen has been reported in ticks and vertebrate hosts as far north and east as Maine [47,49,57], as far south as Texas [58], and as far west as California [32]. The presence of B. odocoilei in California is notable because it has been detected in desert bighorn sheep, a non-cervid vertebrate host, which is outside the normal distribution of I. scapularis ticks [32]. Of biogeographical significance, $B$. odocoilei has been detected in the western blacklegged tick, Ixodes pacificus, and, thus, could be a vector infecting bovids in California. North of the Canada-U.S. border, B. odocoilei has been reported in Ontario [35,39-41], Quebec [35], and Saskatchewan [26]. Additionally, other epidemiological studies have reported B. odocoilei causing fatal outcomes in bovid species in captivity [32,33].

Ecologically, the number of I. scapularis adults in the spring is lower than the full complement of adults in the fall because the number of questing females goes down as they parasitize hosts, and remain in quiescence until spring to lay eggs. By spring, the number of adults is predictably lower. As I. scapularis females parasitize suitable hosts, the number of questing females decreases.

Of epidemiological significance, B. microti has also been detected in the Huronia area in the Ixodes cookei (groundhog tick) [39]. As I. cookei does not parasitize songbirds, B. microti is most likely established in the area. Therefore, people may become infected with this babesial piroplasm.

Songbirds play an important role in the wide dispersal of B. odocoilei-positive I. scapularis [39-41]. Therefore, people do not have to visit an endemic area to contract babesiosis. The symbiosis of blacklegged ticks and white-tailed deer in a sylvatic habitat provides the strategic components for a B. odocoilei endemic area. White-tailed deer are hosts of I. scapularis, especially males and female adults, and promote the propagation of this tick species. Currently, there is no risk map in Ontario for Babesia, so there is no way to see where these areas are located. Holding fast to the dogma that one must visit an endemic area might hamper the assessment and whereabouts of these areas by epidemiologists and healthcare providers. Any of the B. odocoilei-positive sites in southern Ontario may have been initiated by songbirds infested with B. odocoilei-infected I. scapularis larvae and nymphs. Migratory songbirds can transport bird-feeding ticks from as far south as equatorial South America [59-67], and potentially start a new foci of I. scapularis that is hundreds of kilometres from its original source [68-71]. These established populations of I. scapularis may unknowingly be infected with $B$. odocoilei.

Even though the pathogenicity in cats, dogs, and humans has not been clarified for B. odocoilei, this piroplasm is in the same clade/group as Babesia divergens and Babesia venatorum (Figure 2), both of which are pathogenic to humans [1,4]. In essence, healthcare providers must be vigilant to look for human babesosis in symptomatic patients, especially when bitten by blacklegged ticks.

\section{Conclusions}

We provide the first documentation of B. odocoilei in I. scapularis ticks collected from domestic dogs and cats in Canada. Of 21 ticks collected from domestic cats and domestic dogs, 71\% were confirm positive for B. odocoilei. Babesia odocoilei-positive I. scapularis 
ticks collected by flagging low-level vegetation exhibited widespread distribution in Ontario. Since white-tailed deer and songbirds transport B. odocoilei across the Ontario landscape, vertebrate hosts do not need to visit an endemic area to become infected with this babesial piroplasm.

Author Contributions: J.D.S. provided sourcing, collection, identification of ticks, writing of manuscript, and coordination of tick data. E.L.P. conducted analysis of dataset, writing manuscript, and completing phylogenetic analysis. M.S.S. tested ticks and compiled data spreadsheets. J.E.F. supervised lab procedures. All authors have read and agreed to the published version of the manuscript.

Funding: Funding for this study was facilitated in part by the Mary Alice Holmes Memorial Foundation and, also, by a philanthropic donor Diane Kindree. J.E.F. and E.L.P. acknowledge funding from the Pacific Southwest Regional Center of Excellence for Vector-Borne Diseases allocated by the U.S. Centers for Disease Control and Prevention (Cooperative Agreement 1U01CK000516).

Institutional Review Board Statement: Not applicable.

Informed Consent Statement: Not applicable.

Data Availability Statement: Not applicable.

Acknowledgments: We thank veterinarians and veterinary technicians for collecting ticks from domestic animals. We laud Amanda Green for computer graphics.

Conflicts of Interest: The authors declare no conflict of interest.

\section{References}

1. Schnittger, L.; Rodriguez, A.E.; Florin-Christensen, M.; Morrison, D.A. Babesia: A world emerging. Infect. Gen. Evol. 2012, 12, 1788-1809. [CrossRef] [PubMed]

2. Reubush, T.K., II; Cassaday, P.S.; Marsh, H.J.; Lisker, S.A.; Voorhees, D.B.; Maloney, E.B.; Healy, G.R. Human babesiosis on Nantucket Island. Clinical features. Ann. Intern. Med. 1977, 86, 6-9. [CrossRef] [PubMed]

3. Vannier, E.; Krause, P.J. Human babesiosis. N. Eng. J. Med. 2012, 366, 2397-2407. [CrossRef] [PubMed]

4. Herwaldt, B.L.; Cacciò, S.; Gherlinzoni, F.; Aspöck, H.; Siemenda, S.B.; Piccaluga, P.; Martinelli, G.; Edelhofer, R.; Hollenstein, U.; Poletti, G.; et al. Molecular characterization of a non-Babesia divergens organism causing zoonotic babesiosis in Europe. Emerg. Infect. Dis. 2003, 9, 942-948. [CrossRef] [PubMed]

5. Škrabalo, Z.; Deanović, Z. Piroplasmosis in man: Report on a case. Doc. Med. Geogr. Trop. 1957, 9, 11-16. [PubMed]

6. Anderson, J.F.; Mintz, E.D.; Gadbaw, J.J.; Magnarelli, L.A. Babesia microti, human babesiosis, and Borrelia burgdorferi in Connecticut. J. Clin. Microbiol. 1991, 29, 2779-2783. [CrossRef]

7. Herwaldt, B.L.; Persing, D.H.; Precigout, E.A.; Goff, W.L.; Mathiesen, D.A.; Taylor, P.W.; Eberhard, M.L.; Gorenflot, A.F. A fatal case of babesiosis in Missouri: Identification of another piroplasm that infects humans. Ann. Intern. Med. 1996, 124, 643-650. [CrossRef]

8. Homer, M.J.; Aquilar-Delfin, I.; Telford, S.R., III; Krause, P.J.; Persing, D.H. Babesiosis. Clin. Microbiol. Rev. 2000, 13, 451-469. [CrossRef] [PubMed]

9. Hatcher, J.C.; Greenberg, P.D.; Antique, J.; Jimenez-Lucho, V.E. Severe babesiosis in Long Island: Review of 34 cases and their complications. Clin. Infect. Dis. 2001, 32, 1117-1125. [CrossRef] [PubMed]

10. Centeno-Lima, S.; Do Rosário, V.; Parreira, R.; Maia, A.J.; Freudenthal, A.M.; Nijhof, A.M.; Jongejan, F. A fatal case of human babesiosis in Portugal: Molecular and phylogenetic analysis. Trop. Med. Int. Health 2003, 8, 760-764. [CrossRef]

11. Herwaldt, B.L.; De Bruyn, G.; Pieniazek, N.J.; Homer, M.; Lofy, K.H.; Siemenda, S.B.; Fritsche, T.R.; Persing, D.H.; Limaye, A.P. Babesia divergens-like infection, Washington State. Emerg. Infect. Dis. 2004, 10, 622-629. [CrossRef]

12. Gelfand, J.A. Babesia. In Mandell, Douglas and Bennett's Principles of Practice of Infectious Diseases, 4th ed.; Mandell, G.L., Bennett, J.E., Dolin, R., Eds.; Churchill Livingstone: New York, NY, USA, 1995; Volume 2, pp. 2497-2500.

13. Gubernot, D.M.; Nakhasi, H.L.; Mied, P.A.; Asher, D.M.; Epstein, J.S.; Kumar, S. Transfusion-transmitted babesiosis in the United States: Summary of workshop. Transfusion 2009, 49, 2759-2771. [CrossRef] [PubMed]

14. Bloch, E.M.; Herwaldt, B.L.; Leiby, D.A.; Shaieb, A.; Herron, R.M.; Chervenak, M.; Reed, V.V.; Hunter, R.; Ryals, R.; Hagar, W.; et al. The third described case of transfusion-transmitted Babesia duncani. Transfusion 2012, 52, 1517-1522. [CrossRef] [PubMed]

15. Villatoro, T.; Karp, J.K. Transfusion-transmitted babesiosis. Arch. Pathol. Lab. Med. 2019, 143, 130-134. [CrossRef] [PubMed]

16. Brennan, M.B.; Herwaldt, B.L.; Kazmierczak, J.J.; Weiss, J.W.; Klein, C.L.; Leith, C.P.; He, R.; Oberley, M.J.; Tonnetti, L.; Wilkins, P.P.; et al. Transmission of Babesia microti parasites by solid organ transplantation. Emerg. Infect. Dis. 2016, 22, 1869-1876. [CrossRef] [PubMed]

17. Fox, L.M.; Winger, S.; Ahmed, A.; Arnold, A.; Chou, J.; Rhein, L.; Levy, O. Neonatal babesiosis: Case report and review of the literature. Pediatr. Infect. Dis. J. 2006, 25, 169-173. [CrossRef] 
18. Cornett, J.K.; Malhotra, A.; Hart, D. Vertical transmission of babesiosis from a pregnant, splenectomized mother to her neonate. Infect. Dis. Clin. Pract. 2012, 20, 408-410. [CrossRef]

19. Kjemtrup, A.M.; Conrad, P.A. Human babesiosis: An emerging tick-borne disease. Int. J. Parasitol. 2000, 30, 1323-1337. [CrossRef]

20. Scott, J.D. First record of locally acquired human babesiosis in Canada caused by Babesia duncani: A case report. SAGE Open Med. Case Rep. 2017, 5, 2050313-17725645.

21. Shih, C.M.; Liu, L.P.; Chung, W.C.; Ong, S.J.; Wang, C.C. Human babesiosis in Taiwan: Asymptomatic infection with a Babesia microti-like organism in a Taiwanese woman. J. Clin. Microbiol. 1997, 35, 450-454. [CrossRef]

22. Ord, R.L.; Lobo, C.A. Human babesiosis: Pathogens, prevalence, diagnosis, and treatment. Cur. Clin. Microbiol. Rep. 2015, 2, 173-181. [CrossRef]

23. Emerson, H.R.; Wright, W.T. The isolation of a Babesia in white-tailed deer. Bull. Wildl. Dis. Assoc. 1968, 4, 142-143. [CrossRef]

24. Emerson, H.R.; Wright, W.T. Correction. J. Wildl. Dis. 1970, 6, 519. [CrossRef]

25. Holman, P.J.; Madeley, J.; Craig, T.M.; Allsopp, B.A.; Allsopp, M.T.; Petrini, K.R.; Waghela, S.D.; Wagner, G.G. Antigenic, phenotypic and molecular characterization confirms Babesia odocoilei isolated from three cervids. J. Wildl. Dis. 2000, 36, 518-530. [CrossRef]

26. Pattullo, K.M.; Wobeser, G.; Lockerbie, B.P.; Burgess, H.J. Babesia odocoilei infection in a Saskatchewan elk (Cervus elaphus canadensis) herd. J. Vet. Diagn. Investig. 2013, 25, 535-540. [CrossRef]

27. Waldrup, K.A.; Kocan, A.A.; Barker, R.W.; Wagner, G.G. Transmission of Babesia odocoilei in white-tailed deer (Odocoileus virginianus) by Ixodes scapularis (Acari: Ixodidae). J. Wildl. Dis. 1990, 26, 390-391. [CrossRef]

28. Perry, B.D.; Nichols, D.K.; Cullom, E.S. Babesia odocoilei Emerson and Wright, 1970 in white-tailed deer, Odocoileus virginianus (Zimmermann), in Virginia. J. Wildl. Dis. 1985, 21, 149-152. [CrossRef]

29. Holman, P.J.; Waldrup, K.A.; Wagner, G.G. In vitro cultivation of a Babesia isolated from a white-tailed deer (Odocoileus virginianus). J. Parasitol. 1988, 74, 111-115. [CrossRef]

30. Holman, R.J.; Craig, T.M.; Doan-Crider, D.L.; Petrini, K.R. Culture isolation of partial characterization of a Babesia sp. from a North American elk (Cervus elaphus). J. Wildl. Dis. 1994, 30, 460. [CrossRef] [PubMed]

31. Holman, P.J.; Bendele, K.G.; Schoelkopf, L.; Jones, R.L. Ribosomal RNA analysis of Babesia odocoilei isolates from farmed reindeer (Rangifer tarandus tarandus) and elk (Cervus elaphus canadensis) in Wisconsin. Parasitol. Res. 2003, 91, 378-383. [CrossRef] [PubMed]

32. Schoelkopf, L.; Hutchinson, C.E.; Bendele, K.G.; Goff, W.L.; Willette, M.; Rasmussen, J.M.; Holman, P.J. New ruminant hosts and wider geographic range identified for Babesia odocoilei (Emerson and Wright 1970). J. Wildl. Dis. 2005, 41, 683-690. [CrossRef]

33. Bartlett, S.L.; Abou-Madi, N.; Messick, J.B.; Birkenheuer, A. Diagnosis and treatment of Babesia odocoilei in captive reindeer (Rangifer tarandus tarandus) and recognition of three novel host species. J. Zoo Wildl. Med. 2009, 40, 152-159. [CrossRef] [PubMed]

34. Keirans, J.E.; Hutcheson, H.J.; Durden, L.A.; Klompen, J.S.H. Ixodes (Ixodes) scapularis (Acari: Ixodidae): Redescription of all active stages, distribution, hosts, geographical variation, and medical and veterinary importance. J. Med. Entomol. 1996, 33, 297-318. [CrossRef] [PubMed]

35. Scott, J.D.; Pascoe, E.L.; Sajid, M.S.; Foley, J.E. Detection of Babesia odocoilei in Ixodes scapularis ticks collected from songbirds in Ontario and Quebec, Canada. Pathogens 2020, 9, 781. [CrossRef] [PubMed]

36. Young, A.; Morzaria, S.P. Biology of Babesia. Parasitol. Today 1986, 2, 211-219. [CrossRef]

37. Mehlhorn, H.; Shein, E. The piroplasms: Life cycle and sexual stages. Adv. Parasitol. 1985, 23, 37-103.

38. Nicholson, W.A.; Sonenshine, D.E.; Noden, B.H. Ticks (Ixodida). In Medical and Veterinary Entomology, 3rd ed.; Mullen, G.R., Durden, L.A., Eds.; Academic Press/Elsevier: London, UK, 2019; pp. 603-672.

39. Scott, J.D.; Clark, K.L.; Coble, N.M.; Ballantyne, T.R. Detection and transstadial passage of Babesia species and Borrelia burgdorferi sensu lato in ticks collected from avian and mammalian hosts in Canada. Healthcare 2019, 7, 155. [CrossRef]

40. Scott, J.D.; Clark, K.L.; Coble, N.M.; Ballantyne, T.R. Presence of Babesia odocoilei and Borrelia burgdorferi sensu stricto in a tick and dual parasitism of Amblyomma inornatum and Ixodes scapularis on a bird in Canada. Healthcare 2019, 7, 46. [CrossRef] [PubMed]

41. Milnes, E.L.; Thornton, G.; Léveillé, A.N.; Delinatte, P.; Barta, J.R.; Smith, D.A.; Nemeth, N. Babesia odocoilei and zoonotic pathogens identified from Ixodes scapularis ticks in southern Ontario, Canada. Ticks Tick Borne Dis. 2019, 10, 670-676. [CrossRef]

42. Keirans, J.E.; Clifford, C.M. The genus Ixodes in the United States: A scanning electron microscope study and key to the adults. J. Med. Entomol. 1978, 15, 1-38. [CrossRef]

43. Casati, S.; Sager, H.; Gern, L.; Piffaretti, J.-C. Presence of potentially pathogenic Babesia sp. for human in Ixodes ricinus in Switzerland. Ann. Agric. Environ. Med. 2016, 13, 65-70.

44. Edgar, R.C. MUSCLE: Multiple sequence alignment with high accuracy and high throughput. Nucleic Acids Res. 2004, 32, 1792-1797. [CrossRef] [PubMed]

45. Kumar, S.; Stecher, G.; Li, M.; Knyaz, C.; Tamura, K. MEGA X: Molecular evolutionary genetics analysis across computing platforms. Mol. Biol. Evol. 2018, 35, 1547-1549. [CrossRef]

46. Darriba, D.; Taboada, G.L.; Doallo, R.; Posada, D. jModelTest 2: More models, new heuristics and parallel computing. Nat. Methods 2012, 9, 772. [CrossRef]

47. Smith, R.P., Jr.; Elias, S.P.; Borelli, T.J.; Missagthi, R.; York, B.J.; Kessler, R.A.; Lubelczyk, C.B.; Lacome, E.H.; Hayes, C.M.; Coulter, M.S.; et al. Human babesiosis. Emerg. Infect. Dis. 2014, 20, 1727-1730. [PubMed]

48. Stock, B.C.; Moncayo, A.; Cohen, S.; Mitchell, E.A.; Williamson, P.C.; Lopez, G.; Garrison, L.E.; Yabsley, M.J. Diversity of piroplasms detected in blood-fed and questing ticks from several states in the United States. Ticks Tick Borne Dis. 2014, 5, 373-380. 
49. Steiner, F.E.; Pinger, R.R.; Vann, C.N.; Abley, M.J.; Sullivan, B.; Grindle, N.; Clay, K.; Fuqua, C. Detection of Anaplasma phagocytophilum and Babesia odocoilei DNA in Ixodes scapularis (Acari: Ixodidae) collected in Indiana. J. Med. Entomol. 2006, 43, 437-442. [CrossRef] [PubMed]

50. Penzhorn, B.L.; Oosthuizen, M.C. Babesia species of domestic cats: Molecular characterization has opened Pandor's box. Front. Vet. Sci. 2020, 7, 134. [CrossRef] [PubMed]

51. Caccio, S.M.; Antunovic, B.; Moretti, A.; Mangili, V.; Marinculic, A.; Baric, R.R.; Siemenda, S.B.; Pieniazek, N.J. Molecular characterisation of Babesia canis canis and Babesia canis vogeli from naturally infected European dogs. Vet. Parasitol. 2002, 106, 285-292. [CrossRef]

52. Kjemtrup, A.M.; Wainwright, K.; Miller, M.; Penzhorn, B.L.; Carreno, R.A. Babesia conradae, sp. nov., a small canine Babesia identified in California. Vet. Parasitol. 2006, 138, 103-113. [CrossRef] [PubMed]

53. Inokuma, H.; Yoshizaki, Y.; Shimada, Y.; Shimada, Y.; Sakata, Y.; Okuda, M.; Onishi, T. Epidemiological survey of Babesia species in Japan performed with specimens from ticks collected from dogs and detection of new Babesia DNA closely related to Babesia odocoilei and Babesia divergens DNA. J. Clin. Microbiol. 2003, 41, 3494-3498. [CrossRef]

54. Lempereur, L.; De Cat, A.; Caron, Y.; Madder, M.; Claerebout, E.; Saegerman, C.; Losson, B. First molecular evidence of potentially zoonotic Babesia microti and Babesia sp. EU1 in Ixodes ricinus in Belgium. Vector Borne Zoonotic Dis. 2011, 11, 125-130. [CrossRef] [PubMed]

55. Akram, I.N.; Parveen, T.; Abrar, A.; Mehmood, A.K.; Iqubal, F. Molecular detection of Babesia microti in dogs and cat blood samples collected from Punjab (Pakistan). Trop. Biomed. 2019, 36, 304-309. [PubMed]

56. Zhang, X.-L.; Li, X.-W.; Li, W.-J.; Huang, H.-L.; Huang, S.-J.; Shao, J.-W. Molecular evidence of Babesia in pet cats in mainland China. BMC Vet. Res. 2019, 15, 476. [CrossRef]

57. Steiner, F.E.; Pinger, R.R.; Vann, C.N.; Grindle, N.; Civetello, D.; Clay, K.; Fuqua, C. Infection and co-infection rates of Anaplasma phagocytophilum variant, Babesia spp., Borrelia burgdorferi, and rickettsial endosymbiont in Ixodes scapularis (Acari: Ixodidae) from sites in Indiana, Maine, Pennsylvania, and Wisconsin. J. Med. Entomol. 2008, 45, 289-297. [CrossRef] [PubMed]

58. Waldrup, K.A.; Kocan, A.A.; Qureshi, T.; Baggett, D.; Wagner, G.G. Serological prevalence and isolation of Babesia odocoilei among white-tailed deer (Odocoileus virginianus) in Texas and Oklahoma. J. Wild. Dis. 1989, 25, 194-201. [CrossRef]

59. Scott, J.D.; Fernando, K.; Banerjee, S.N.; Durden, L.A.; Byrne, S.K.; Banerjee, M.; Mann, R.B.; Morshed, M.G. Birds disperse ixodid (Acari: Ixodidae) and Borrelia burgdorferi-infected ticks in Canada. J. Med. Entomol. 2001, 38, 493-500. [CrossRef] [PubMed]

60. Morshed, M.G.; Scott, J.D.; Fernando, K.; Beati, L.; Mazerolle, D.F.; Geddes, G.; Durden, L.A. Migratory songbirds disperse ticks across Canada, and first isolation of the Lyme disease spirochete, Borrelia burgdorferi, from the avian tick, Ixodes auritulus. J. Parasitol. 2005, 91, 780-790. [CrossRef] [PubMed]

61. Scott, J.D.; Durden, L.A. First isolation of Lyme disease spirochete, Borrelia burgdorferi, from ticks collected from songbirds in Ontario, Canada. N. Am. Bird Bander 2009, 34, 97-101.

62. Scott, J.D.; Lee, M.-K.; Fernando, K.; Durden, L.A.; Jorgensen, D.R.; Mak, S.; Morshed, M.G. Detection of Lyme disease spirochete, Borrelia burgdorferi sensu lato, including three novel genotypes in ticks (Acari: Ixodidae) collected from songbirds (Passeriformes) across Canada. J. Vector Ecol. 2010, 35, 124-139. [CrossRef] [PubMed]

63. Scott, J.D.; Anderson, J.F.; Durden, L.A. Widespread dispersal of Borrelia burgdorferi-infected ticks collected from songbirds across Canada. J. Parasitol. 2012, 98, 49-59. [CrossRef]

64. Scott, J.D.; Durden, L.A. New records of the Lyme disease bacterium in ticks collected from songbirds in central and eastern Canada. Int. J. Acarol. 2015, 41, 241-249. [CrossRef]

65. Scott, J.D.; Clark, K.L.; Foley, J.E.; Bierman, B.C.; Durden, L.A. Far-reaching dispersal of Borrelia burgdorferi sensu lato-infected blacklegged ticks by migratory songbirds in Canada. Healthcare 2018, 6, 89. [CrossRef]

66. Scott, J.D.; Clark, K.L.; Foley, J.E.; Anderson, J.F.; Bierman, B.C.; Durden, L.A. Extensive distribution of the Lyme disease bacterium, Borrelia burgdorferi sensu lato, in multiple tick species parasitizing avian and mammalian hosts across Canada. Healthcare 2018, 6, 131. [CrossRef] [PubMed]

67. Scott, J.D.; Durden, L.A. Amblyomma dissimile (Acari: Ixodidae) parasitizes bird captured in Canada. Syst. Appl. Acarol. 2015, 20, 854-860.

68. Anderson, J.F.; Magnarelli, L.A. Avian and mammalian hosts for spirochete-infected ticks and insects in a Lyme disease focus in Connecticut. Yale J. Biol. Med. 1984, 57, 627-641.

69. Anderson, J.F.; Magnarelli, L.A.; Stafford, K.C., III. Bird-feeding ticks transstadially transmit Borrelia burgdorferi that infect Syrian hamsters. J. Wildl. Dis. 1990, 26, 1-10. [CrossRef]

70. Scott, J.D.; Scott, C.M.; Anderson, J.F. The establishment of a blacklegged tick population by migratory songbirds in Ontario. J. Vet. Sci. Med. 2014, 2, 5. [CrossRef]

71. Scott, J.D.; Pascoe, E.L.; Sajid, M.S.; Foley, J.E. Monitoring of nesting songbirds detects established population of blacklegged ticks and associated Lyme disease endemic area in Canada. Healthcare 2020, 8, 59. [CrossRef] [PubMed] 